\title{
Digital dannelse for ældre Undervisning af ældre i it efter Digitaliseringsstrategien
}

\begin{abstract}
This article presents the result of observational studies and interviews conducted of two types of it-education aimed at the elderly. The purpose is to illuminate how the volunteers at these learning facilities approach the needs and wants that older adults may have following the Digitization Strategy of 2014. The approach is mainly based on participant observations and interviews. The major finding of this study is that the focus of the volunteers extends far beyond the instrumental demands put on older adults by the Digitization Strategy. The focus is instead on a long line of other skills, and the volunteers can be said to guide their users towards a type of digital bildung (da: "digital dannelse"). In this digital bildung, as opposed to the implicit demands of national strategies and much previous research, the priority is on a self-guided and interest-focused approach to the medium of the computer. Occasionally this also includes a conscious rejection of the specific services that citizens are required to use according to the Digitization Strategy.
\end{abstract}

Keywords AEldre og medier, digital dannelse, medieundervisning, digitalisering, it-kompetencer

\section{Indledning}

Siden 2014 har det i Danmark været påkrævet, at langt størstedelen af kontakten imellem offentlige instanser og borgere skal foregå digitalt. Det kræves derfor implicit af borgerne, at de skal kunne besidde en række kompetencer der gør dem i stand til at betjene en computer og en række specifikke tjenester som NemIDi og Digital Postii, samt i al almindelighed at kunne betjene sig af e-mail og hjemmesider. Dette sker til trods for, at en stor del af den danske befolkning, særligt ældre, enten ikke tidligere har været online eller generelt ikke er ligeså flittige brugere af nettet som deres yngre medborgere (Kulturstyrelsen, 2015). Ydermere får en stor del af de ældre tilsyneladende hjælp af andre til at bruge it deres hverdag (Siren \& Knudsen, 2014). Især de mest itfremmede ældre vil ofte benytte sig af familiemedlemmer eller nære venner til at gøre sig bekendte med de nye medieteknologier (Bakardjieva, 2005; 2011). Men hvad så med de ældre, der ikke måtte have nogen i deres nære netværk, der kunne hjælpe dem?

Digitaliseringsstyrelsen, som er ansvarlig for digitaliseringen af den offentlige sektor, henviste i 2014 til et udvalg af tilbud, der kunne hjælpe borgerne med at benytte sig af disse digitale tjenester. Det drejer sig blandt andet om en lang række tilbud drevet af frivillige foreninger. Frivilligheden skal her forstås som "den organiserede frivillighed i tilknytning til foreninger og organisationer, [...] og ikke de mere uformelle former for frivillighed som 
fx forældres hjælp til voksne børn og børnebørn og praktisk hjælp til naboen eller til slægtninge" (Boje, 2014, s. 225). De, der ikke har nære relationer der er i stand til at hjælpe, er altså overladt til disse frivillige tilbud, drevet af foreninger og organisationer.

At et stort ansvar på denne måde lægges over på frivillige foreninger er måske ikke overraskende, taget i betragtning at alle danske regeringer siden begyndelsen af 2000'erne har "betonet værdien af frivilligt arbejde i regeringsgrundlag og forskellige politiske initiativer." (Henriksen, 2014, s. 16). Frivilligheden er da også et udbredt fænomen i Danmark, hvor cirka en tredjedel af den danske befolkning over 16 år på et tidspunkt har udført frivilligt arbejde (Fridberg, 2014, s.33). I denne artikel har jeg valgt at tage udgangspunkt i spørgsmålet omkring hvorvidt disse tilbud - som er uafhængige af Digitaliseringsstyrelsen - blot tjener som en form for hjælp for de mere it-fremmede brugere og disses kontakt med eksempelvis Digital Post, eller om underviserne på disse tilbud ønsker at bibringe andre kompetencer til deres brugere. På baggrund af denne overvejelse søger denne artikel at besvare følgende forskningsspørgsmål:

a. Kan disse undervisningstilbud siges at være med til at hjælpe ældre med at domesticere de nye medieteknologier og herunder også de specifikke løsninger, som digitaliseringsstrategien har implementeret?

b. Er det indholdsmæssige fokus i undervisning på direkte at imødekomme digitaliseringsstrategiens instrumentelle krav, eller er det lagt på andre formål der snarere kan betegnes som at arbejde imod en form for "digital dannelse"?

Med udgangspunkt i den eksisterende forskning, vil jeg først give et mere udførligt overblik over de problemer, som ældre kan stå overfor i et samfund, der i stigende grad afkræver sine borgere digitale kompetencer. Efter dette vil jeg diskutere begreberne "domesticering" og "digital dannelse" og hvordan disse knytter sig særligt til it-fremmede ældre. Endeligt vil jeg udlægge, hvordan disse forhold kommer til udtryk i de undervisningstilbud jeg har undersøgt.

\section{AEldre og it i Danmark - et overblik}

Digitaliseringsstrategien som blev vedtaget af både regering, regioner og kommuner i 2011 medfører at det fra november 2014 kun var muligt at kommunikere med offentlige myndigheder og virksomheder via den digitale selvbetjening og Digital Post. Visse ældre kan dog blive fritaget for den digitale post (Regeringen, KL \& Danske Regioner 2011). I praksis betyder dette at det eksempelvis kun er muligt at melde flytning, bestille nye sundhedskort eller forny pas igennem de digitale medier. Ydermere kan ansøgninger og spørgsmål om offentlige ydelser der ikke længere varetages af kommunerne nu kun ske digitalt (Sommer et al, 2015, s. 34).

Det er vigtigt at holde in mente, at ældre i Danmark udgør en heterogen gruppe af mennesker, med store variationer i deres hverdagsliv og mediebrug (Christensen et al., 2017). At omtale "de ældre" vil altid omfatte en meget forskelligartet gruppe af mennesker (Ganguin \& Haubold, 2017, s. 27).

Ikke desto mindre er det tydeligt at ældre i Danmark ofte kan være udfordrede af en hastig udvikling indenfor IKT-sammenhænge, samt af generelle fysiologiske begrænsninger forbundet med deres egen aldring (se Almeida-Ferreira et al., 2017 for et review). Udover disse fysiologiske begrænsninger, har de ældre også andre medievaner grundet personlige præferencer. Undersøgelser fra udlandet peger på at ældre foretrækker "gamle" massemedier, herunder den trykte avis og flow-tv (Aroldi \& Colombo, 2007) og at de er mere skeptiske end deres yngre medborgere overfor at tage nye medieteknologier til sig (Westlund \& Weibull, 2013; Norris, 2001; Mollenkopf \& Kaspar, 2005). Dette falder i god tråd med forskning der viser, at forskellige generationer i høj grad er præget af det medielandskab de er født ind i, og som eksisterer i deres formative år (Westlund \& Weibull, 2013, s. 147).

I Danmark er hverken køn, uddannelsesbaggrund, indkomst eller geografi "i stand til på samme måde at udløse så store forskelle i mediebrug på nettet, brugen af nye platforme og medieteknologier som alder er" (Kulturstyrelsen 2015, s. 10). 93\% af den danske befolkning i alderen 16-74 år har adgang til Internettet i 
hjemmet, og 83\% af befolkningen brugte i 2013 dagligt computeren (Kulturstyrelsen, 2015). I gennemsnit brugte 81\% af danskerne internettet dagligt i 2014 (ibid.). For aldersgruppen 65-74 var andelen på 65\% imens den for aldersgruppen 75-89 var nede på 31\%, i sidstnævnte aldersgruppe benyttede $41 \%$ sig aldrig af internettet, imens det for den lidt yngre gruppe kun drejede sig om 12\% (ibid.). Eldre kan altså risikere at være en særligt udsat gruppe når det kommer til brugen af digitale medier, hvilket kan vise sig særligt problematisk når det implicit påkræves i en så omfattende offentligt strategi.

\section{Den 'grå', digitale kløft og hvorfor den skal krydses}

Skellet imellem den ældre og yngre del af befolkningen omtales ofte som en "grå kløft" (Friemel, 2016) som skal krydses. Der bliver fremført mange bevæggrunde for at formindske denne grå kløft, samtidig med at der kan være mange forskellige årsager til at fravælge eller at have besvær med de nye medieteknologier.

Digitaliseringsstrategien har altid indeholdt muligheden for at borgeren, såfremt denne opfylder en række krav, kunne blive fritaget for digital kontakt med det offentlige. Pr. december 2016 var status således, at 16,2\% af alle borgere i alderen 65-74 og 43,8\% af borgere i alderen 75-84 år var permanent fritaget for digital post (Digitaliseringsstyrelsen, 2012).

Undersøgelser fra andre lande viser at de ældre der fravælger internettet og computeren kan have mange forskellige bevæggrunde, lige fra bekymringer om at beskytte deres privatliv (e.g. Brandtzæg et al., 2010; Braun, 2013), manglende betydning i hverdagslivet (Harakkarainen, 2012; Sundar et al., 2011; Lampe et al. , 2013), eller en mangel på konceptuel forståelse af digitale tjenester (Quinn et al., 2016).

Det er også vigtigt at holde sig for øje at udvikling af informations- og kommunikationsteknologier foregår i høj hastighed, og dette kan have en høj indflydelse på ældres brug og ikke-brug af disse teknologier (Boyd \& Ellison, 2007; Kim et al., 2007).

Der er således en mangfoldighed af grunde til, at ældre danskere kan være udeladte fra computerverdenen, og der skabes hermed en dybt problematisk kløft imellem computer-brugere og ikke-brugere. Kløften kan føre til en udeladelse af borgere fra politisk information og deltagelse i politiske processer (Bonfadelli, 2002; Norris, 2001) eller manglende social kapital, inklusion og en mangel på et socialt sikkerhedsnet (Livingstone \& Helsper, 2007; Nimrod, 2010; Pfeil et al., 2010; Richardson et al., 2005; Sum et al., 2008).

Ud fra en forestilling om at samfundet generelt efterspørger borgere, der er veluddannede, i arbejde, informerede, kompetente administratorer af deres egen tilværelse og generelt tilfredse (Stald et al., 2015) kan den grå kløft altså være dybt problematisk. Set fra borgernes eget synspunkt, bliver kløften også problematisk, da den kan hindre borgernes stræben efter meningsfuldhed og sammenhæng i hverdagslivet, en identitet og et tilhørsforhold i samfundet, samt et godt og fredeligt liv (ibid., s. 13).

Det tages ofte for givet, at det at kunne være online er et utvetydigt gode (Livingstone \& Helsper, 2007, s.673). Ligeledes ses det i både domesticeringteorien (e.g. Silverstone et al., 1992) og i pædagogiske diskussioner (e.g., Christiansen \& Christensen, 2010) at nye medier, herunder computeren og internettet, ikke bør blive betragtet som "noget andet", men som en naturlig del af hverdagen, samfundet og det levede liv. Som jeg senere vil udlægge, er dette et synspunkt der stemmer overens med mine informanters målsætninger.

I det næste afsnit vil jeg se nærmere på hvordan forskningen har påvist at ældre mennesker kan blive kompetente mediebrugere.

\section{Domesticering: At krydse den digitale kløft}

Det første skridt i at "tæmme" medierne og bringe dem ind i hjemmet og hverdagen, er i litteraturen om domesticering af nye medieteknologier omtalt som "appropriation", hvor teknologier og objekter tages hjem og gøres (eller ikke gøres) acceptable og velkendte (Silverstone \& Haddon, 1996, s. 3). Dette er således en proces, de mest it-fremmede ældre sandsynligvis vil gennemgå. 
Jæger (2003) påpeger, at ældre mennesker som regel er i stand til at erhverve sig en lang række af færdigheder med digitale teknologier, så længe at instruktionen i samme bliver givet på den ældres egne præmisser. Ligeledes har tidligere undersøgelser i Danmark også påvist, hvorledes " Eldrevenligt it-udstyr og brugervenlige hjemmesider" (Forsberg et al., 2013, s. 7) ikke kan stå alene, men skal "suppleres af tiltag, der motiverer, lærer og støtter op om seniorernes it-brug." (ibid., s. 7).

Som nævnt vil nære slægtninge eller venner, med et vist kendskab til den relevante teknologi, ofte bistå den mere it-fremmede bruger. Omkring 25\% af respondenterne i en unders $\varnothing$ gelse af ældre danskeres mediebrug angav, at de fik en form for assistance til deres behov (Siren \& Knudsen, 2014). Bakardjieva (2005; 2011) bruger udtrykket "varme eksperter" som en fællesbetegnelse for disse hjælpere. En varm ekspert er ikke nødvendigvis en ekspert i absolut forstand, men i hvert fald i en relativ forstand, i forhold til den udfordrede bruger, som de hjælper. Den varme ekspert er i stand til at bygge bro imellem universaliteten i it-teknologien og brugerens konkrete behov, situation og baggrund (Bakardjieva, 2005, s. 95).

Dette falder i tråd med en grundlæggende tese i den såkaldte "domesticerings-teori", nemlig at folk "konstruerer deres egen teknologiske praksis, men i interaktion med andre folks teknologiske praksisser" (Sørensen, 2004, s. 1). I den digitale interaktion med danske offentlige institutioner, kan denne assistance og interaktion være alt fra et hurtigt telefonopkald, til en samtale ved et tilfældigt møde og til mere formelt planlagte arrangementer (Madsen og Kræmmergaard, 2016, s. 92)

Eldre tager som regel først nye teknologier til sig, hvis de opfatter fordele ved at have disse i deres hverdagsliv (Melenhorst et al., 2006). Nogle gange kan denne motivation komme i form af et oplevet pres fra banker eller offentlige institutioner. I andre tilfælde kan det være lysten til at have kontrol over eget liv eller pleje af allerede eksisterende interesser og hobbyer, og at kunne vedligeholde og opbygge meningsfyldte relationer (Digitaliseringsstyrelsen, 2012, s. 2-3).

Tidligere undersøgelser har vist, at ældre førstegangs-brugere af computere og internettet ofte har haft svært ved selv at definere deres egne formål med den nye teknologi (Sawchuk \& Lafontaine, 2015). Derfor bliver det særligt vigtigt, hvilken hjælp og assistance der gives til den mindre erfarne bruger. Begribeligvis skal der både beherskes basale kundskaber som at betjene sig af tastatur og mus, men også mere kritiske kundskaber skal oparbejdes, samtidig med at brugeren skal se en mening med brugen af den nye medieteknologi.

\section{Instrumentelle krav og digital dannelse}

De implicitte, instrumentelle krav som Digitaliseringsstrategien stiller overfor borgeren, beskæftiger sig blot med kompetencerne til at kunne betjene den Digitale Post og relaterede på hjemmesider og tjenester. Groft sagt skal en ældre borger "kun" være i stand til at navigere disse hjemmesider og forstå og reagere på de informationer de måtte modtage herigennem for at leve op til de instrumentelle krav.

I modsætning til denne instrumentelle tilgang står diverse forestillinger om en "digital dannelse". "Digital dannelse" er et begreb, der er brugt i mange sammenhænge, men som ikke må direkte forveksles med begreber som "media literacy", "computer literacy" og "digital literacy". Som Stald et al (2015) udpeger, så er enhver af disse udlægninger "afhængig af faglig og kulturel kontekst, forskningsmæssige fagtraditioner, historiske traditioner og normative vurderinger, der knytter sig til særlige områder, så som læring, kulturforståelse og politik" (2015, s. 8).

Der er flere bevæggrunde for, at jeg vælger at anvende udtrykket "digital dannelse" fremfor et beslægtet engelsksproget begreb. Først og fremmest er det for at følge anbefalingen om at man "i en dansk sammenhæng inddrager begrebet dannelse i forståelsen af media literacy, men i en genfortolkning, der frig ør det fra en normativ forståelse i traditionel forstand." (Stald et al 2015, s. 9). Ligesom Stald et al. er jeg inspireret af Lars Qvortrup's udlægning, der siger at "dannelsens funktion i et hyperkomplekst samfund er at administrere hyperkompleksitet." (Qvortrup, 2000, s. 301). Dette vil, i min udlægning, blandt andet involvere hvilke aspekter 
af de digitale medier man som enkeltperson vil og ikke vil inddrage i sit liv. Den digitale dannelse jeg udlægger her, er altså at betragte som en tilgang til medierne der er refleksiv og ikke-normativ, for så vidt at den ikke blot er en stræben efter at imødekomme instrumentelle krav. Dette skal forstås i modsætning til et normativ, og instrumentelt betonet fokus på digitale kompetencer.

Ud over dette er det for at fremhæve modsætning til begrebet om "halvdannelsen" eller forestillingen om at formålet med uddannelse alene er at erhverve kompetencerne til at gebærde sig konkurrencedygtigt i samfundet (jf. Kemp 2015, s. 116).

"Digital dannelse" bliver af flere forfattere i nordiske lande italesat som en vedvarende, refleksiv proces en person gennemgår, for at vurdere og tage højde for den betydning, de digitale medier har fået i det nuværende samfund (Buckingham, 2006; Drotner, 2008; Hoem, 2003; Nyboe, 2009; Levinsen \& Sørensen, 2011; Løvlie, 2003). Digital dannelse forudsætter altså en række kompetencer, men kompetencerne gør ikke dannelsen alene.

"Digital dannelse" dækker altså over mere end blot kompetencerne til at betjene sig af de nye medieteknologier. Det dækker også, blandt andet, over den enkeltes evne til at udføre kritisk refleksion omkring medieteknologiernes betydning, samt eventuelle risici omkring brugen af disse, men også et fokus på de muligheder for udfoldelse som der følger med (jf. Third et al., 2014).

I min undersøgelse vil jeg afklare, om de frivillige kun $s \varnothing g e r$ at hjælpe deres brugere til at kunne klare de instrumentelle krav som digitaliseringsstrategien stiller, eller om deres virke rækker ud over dette formål? Kan de frivillige siges at fors $\varnothing$ ge at viderebringe en "digital dannelse" til deres brugere? Det skal holdes for at øje, at min brug af udtrykket "digital dannelse" her er min egen analytiske beskrivelse, og ikke et begreb anvendt af mine informanter.

\section{Metode}

Nærværende unders øgelse af ældres mediebrug baserer sig på feltobservationer og interviews, foretaget på to undervisningstilbud, organiseret med frivillig arbejdskraft for ældre, der gerne vil lære at benytte IT eller få hjælp til specifikke it-formål. Empirien består af otte semi-strukturerede interviews, optagede og transskriberede (se Kvale, 1994), fire uformelle interviews, rekonstrueret i feltnoter (DeWalt \& DeWalt, 2011), samt i alt otte dages feltobservationer udført i oktober og november 2016 af undervisningen på disse tilbud.

Fokus er valgt på underviserne fremfor de ældre der benyttede sig at it-tilbuddene. Dette er motiveret af en række faktorer. Først og fremmest $\emptyset$ nskede jeg et indblik i undervisernes overvejelser og praksisser med at tilgå mere eller mindre it-udfordrede brugere. Dernæst var jeg interesseret i dem, som repertoirer af en lang række erfaringer omkring, hvem disse brugere var, og hvilke udfordringer de kom med. De fleste af mine interviewpersoner har været tilknyttet som frivillige i flere år, og har således undervist ældre i en tid både før, under og efter digitaliseringsstrategiens implementering. De har således en rig erfaring, som jeg fors øger at få belyst.

Observationerne af selve undervisningen har været af en forholdsvist ikke-deltagende karakter (jf. DeWalt \& Dewalt, 2011, s. 24-25), da jeg mestendels kun kort har introduceret mig selv for brugerne, og har haft nogle korte interaktioner med de frivillige, for så efterfølgende at observere undervisningen.

\section{Kontekst}

Selvom de to tilbud jeg har undersøgt havde lignende formål, så var der dog nogle nævneværdige forskelle. Det ene (en såkaldt "Datastue") fulgte primært en struktureret holdplan, hvor ældre var tilmeldt bestemte hold af undervisning, som løb for et år af gangen, hvorimod det andet (forestået af $Æ$ Eldresagen) primært havde karakter af et åbent værksted, hvor brugere kunne komme og gå efter behov, blot de var medlemmer af $\mathscr{E}$ Eldresagen. AEldresagens tilbud lå i København, og det andet var drevet af en uafhængig, frivillig forening, lå i Region Syddanmark. 
De konkrete undervisningstilbud er primært valgt ud fra en forestilling om en vis forskellighed tilbuddene imellem, både $\mathrm{i}$ forhold til deres beliggenhed, brugerbase og strukturen af den service, de tilbød. Denne forskellighed eksisterede blandt andet ved, at det ene tilbud lå i København, det andet i Region Syddanmark, som er den region der har det $h ø j$ jeste procenttal af befolkningen (15\%), som har fået dispensation til fritagelse fra digital post (Danmarks Statistisk, 2016). Det ene tilbud var drevet af frivillige i ÆEldresagen, det andet af en frivillig forening, som havde tilknytning til netværket Datastuerne. Det ene tilbud fulgte en selvbeskrevet "cafetilgang", hvor brugerne kunne komme og gå efter forgodtbefindende og løse konkrete problemstillinger. Underviserne sammenlignede sig selv med it-afdelingen på en arbejdsplads.

På det syddanske tilbud var undervisningen planlagt på forhånd af en underviser, dog med en del indflydelse fra dennes elever, som jeg senere skal vende tilbage til. Her vil jeg også gå i nærmere detaljer med hvilke emner der blev behandlet på tilbuddene.

Den største datamængde i denne artikel, er taget fra de formelle interviews, som er foretaget med underviserne på de forskellige tilbud. Udover dette har flere uformelle samtaler med brugere og observationer af samtaler deltagerne imellem også fundet sted. Interviews og feltnoter er efterfølgende blevet underlagt en iterativ kvalitativ kodningsproces for at belyse spørgsmål og klarlægge temaer.

\section{Beskrivelse af undervisningstilbuddene}

Som tidligere nævnt var de to undervisningstilbud forskellige i form af deres organisatoriske tilknytninger, beliggenhed og generelle undervisningsform.

I det følgende vil jeg, for læsevenlighedens skyld omtale de ældre der benytter sig af disse tilbud som "brugere", og omtale de (næsten udelukkende ældre) frivillige, der er ansvarlige for driften af disse tilbud, som "de frivillige" eller "underviserne" selvom deres rolle i konkrete tilfælde havde mere karakter af at være vejleder eller konsulent.

Alle underviserne jeg talte med var mænd, alle var frivillige og med undtagelse af en enkelt, der var deltidsansat, var de alle pensionerede. Kun én af mine interviewpersoner havde en fortid som decideret underviser, nærmere bestemt voksenundervisning i forbindelse med forsvarets uddannelser. Enkelte af dem havde særskilt faglig baggrund i IT, men som en af dem formulerede det, var det "en IT-baggrund fra forrige årtusinde".

Generelt stemmer profilen på underviserne overens med profilen på undervisere på et andet IT-projekt for ældre i Greve Kommune (Sommer et al., 2015) bortset fra det komplette fravær af yngre frivillige i eksempelvis gymnasiealderen, som deltog i projektet i Greve. Dette peger på at IT-undervisningen af ældre mestendels forestås af ældre.

Alle de brugere der benyttede sig af tilbuddene i løbet af mine observationer var pensionerede, og langt størstedelen var umiddelbart tilknyttet lokalområderne for deres respektive tilbud. Brugernes egne evner var af stærkt varierende karakter, lige fra folk der aldrig havde ejet en pc til pensionister med en baggrund i EDB eller computerprogrammering.

Undervisningen og assistancen var overvejende fokuseret på betjeningen af computere. På det syddanske tilbud var der særskilt undervisning i brug af iPads, og folk på begge tilbud søgte lejlighedsvist hjælp til brug af deres smartphones, om end underviserne som oftest $\varnothing$ nskede at sende dem videre til deres teleudbydere.

I det følgende vil jeg mestendels fokusere på undervisernes tilgang til hjælp og undervisning med hjemmecomputere og bærbare computere.

\section{IT-tilbuddene som springbræt til domesticering af medieteknologier}

I domesticeringsteorien arbejdes der ud fra en forestilling om, at enhver bemægtigelse af nye medieteknologier begynder når det nye udstyr "tages i besiddelse af et individ eller en husstand" (Silverstone et al., 1992, s. 21). 
Derfor har jeg valgt at se nærmere på, hvordan underviserne på disse tilbud har håndteret nogle af de mest itfremmede brugeres mangel på erfaring med computerteknologier. Dette kan være brugere der kun i et meget begrænset omfang, eller slet ikke, har haft omgang med computere før.

Tilbuddene har været et springbræt for flere ældre til at blive ejere af computere, og underviserne bliver ofte udspurgt af nye og potentielle brugere omkring disses $k \varnothing b$ af computere. En underviser formulerede det som at "hjælpe dem med at lave en behovsanalyse".

Selv de brugere der allerede måtte have erhvervet sig en computer, er ikke nødvendigvis trygge med den. Her understregede de fleste af undervisere, hvordan de prøvede at hjælpe disse brugere til at blive mere tilpasse med deres udstyr. Én underviser på det københavnske tilbud formulerede det således:

Så du kan sige at meget af det vi laver hernede, det går også ud på at vænne folk til ... "du kan aldrig gøre noget galt", den slår dig ikke, den brænder ikke, den gør ikke nogen grimme ting, den brænder ikke ned igennem bordpladen eller sådan noget lignende. (Underviser C)

Hermed har underviserne som målsætning at modarbejde den følelse som mange "it-fremmede" har, hvor de kan føle sig "usikre og nervøse ved mødet med it." (Digitaliseringsstyrelsen 2012, s. 1) og kan være "bange for at gøre noget forkert, de taler ikke sproget, og de føler sig uden for fællesskabet." eller endeligt "holder sig på afstand og ser it som noget unaturligt, som de ikke umiddelbart oplever noget behov for at lære at kende" (ibid.).

Omvendt beretter underviserne også om at de har haft erfaringer med at hjælpe brugere med fritagelser fra Digitale Post. En underviser udlægger en sådan historie således:

Jeg har haft to som jeg direkte anbefalede at tage ind [på Borgerservice] og få en fritagelse. Og den ene, det var en ældre herre på 83. Altså han var simpelthen ved at gå i spåner. "Jeg sover ikke om natten!" sagde han. "Åh mit hoved det suser rundt". Så sagde jeg "Tag nu ind og få en fritagelse. Og ring til mig når du er derinde." Så gik der et par uger, så ringede han. Nu havde han været derinde. "Så du er lettet nu?" Ja det var han. "Men det kan godt være jeg kommer igen". "Jamen det er da også i orden" sagde jeg. (Underviser F)

Fravalget af Digital Post er altså ikke nødvendigvis en komplet afvisning af livet med computermediet, og denne underviser åbner her på for betragtning om, at Digital Post ikke er en nødvendighed i alle deres ældre brugeres hverdagsliv. På denne måde går de klart imod en rent instrumentel tilgang til at have computermediet og en online tilstedeværelse i deres brugeres hverdag. Den tilgang de frivillige fremfører er altså ikke nødvendigvis overlappende med Digitaliseringsstyrelsens implicitte krav til borgerne.

Samtidigt berettede flere af underviserne også om, at tvangsdigitaliseringen i løbet af 2014 og 2015 førte til en lang række nye brugere af tilbuddet, som søgte hjælp med Digitaliseringsstyrelsens løsninger som NemID og Digital Post. Disse var dog som regel ikke brugere der endte med at blive en fast del af tilbuddene. Ifølge underviserne ville de erhverve sig de specifikke kompetencer, som de mente var nødvendige i forhold til at kunne betjene sig af de nye, påkrævede it-løsninger, for så efterfølgende at forsvinde. Tvangsdigitaliseringen har således, ifølge underviserne selv, ikke været den primære årsag til at folk har valgt at benytte sig af undervisningstilbuddene.

Underviserne på disse tilbud er altså hjælpsomme og prøver at sætte sig i deres it-fremmede brugeres sted. Samtidig udviser de også en bevidsthed omkring, at det ikke er i alle brugeres interesse at benytte sig af de offentlige it-ydelser, som måske har drevet dem til it-tilbuddene til at begynde med. Det er dog værd at holde sig for $\emptyset j e$, at en fritagelse fra den digitale kontakt med det offentlige ikke nødvendigvis er lig med en komplet afvisning af computeren som medie, eller behovet for hjælp med samme. Hvad det især ikke er lig med, er afvisning af brugen af undervisningstilbuddene, der kan fungere som en social arena for de ældre. Dette er et aspekt jeg diskuterer nærmere herunder. 


\section{Domesticering uden for hjemmet}

Som navnet antyder, beskæftiger domesticerings-teorien sig med hjemmet. Mit undersøgelsesfelt i denne artikel er som nævnt udenfor hjemmet, men der er alligevel $i$ både mine observationer og interviews antydninger af udsagn omkring hvorvidt mange af brugerne tager computerteknologien til sig i hjemmet.

På begge undervisningstilbud var der erfaringer med brugere der, efter undervisernes bedste overbevisning benyttede sig af tilbuddene som en tryg ramme, hvor de kan praktisere deres gøremål med deres eget digitale udstyr. Som én underviser på det cafe-baserede, Københavnske tilbud formulerede det:

Der kommer enkelte, hvor man godt kan få fornemmelsen af, at de måske mest kommer for at.. Øhhh hyggens skyld. Så.. eller måske fordi deres internetforbindelse derhjemme ikke er så stærk som vores. Men øhh.. Dem lader vi jo bare sidde. Får de så brug for hjælp, så får de hjælp. Sommetider har man indtryk af de finder på et eller andet lille bitte problem for sådan at legitimere at de har været her. (Underviser B)

For nogle brugere bliver disse tilbud altså trygge rammer, hvor de kan udøve deres gøremål med computerne. Dette kan både være i kraft af de frivillige og disses tilgang til computermediet, og på det syddanske tilbud også $i$ kraft af det sociale samvær med de andre brugere.

På det syddanske tilbud kom mange af de ældre brugere tilsyneladende også for at nyde hinandens selskab. Den hold-baserede undervisning gjorde, at mange af brugerne var bekendte med hinanden, og kaffepauserne $\mathrm{i}$ undervisningen trak for det meste ud med en livlig og uformel snak, hvor både brugere og undervisere deltog. Nogle af undervisernes udsagn på det syddanske tilbud gjorde det da også klart at "hyggen" og "samværet" efter deres mening spillede en stor rolle i forhold til, at brugerne valgte at deltage. For nogle, spekulerede de, var den måske mere vigtig end selve undervisningens indhold.

Et gentagende refræn ytret af mange brugere i løbet af undervisningen var variationer af "ja det er smart, men hvordan husker man det?". Dette var også tilfældet, når undervisningen faldt på emner, som kan forekomme selvfølgelige for mere rutinerede computerbrugere, eksempelvis at benytte sig af genvejstaster eller at flytte filer fra én mappe til en anden. Dette tager jeg som et klart tegn på, at mange af disse brugere kun sjældent eller aldrig benyttede sig af disse funktioner i deres udstyr hjemme. Dette bliver også underbygget af flere af undervisernes udsagn omkring, at "mange ældre mennesker ikke bruger deres computer derhjemme".

Ulempen ved dette er så, at aktiviteten med computermediet kan blive noget, der kun finder sted på undervisningstilbuddene. Flere af underviserne udtrykker en mistanke om, at deres ældre bruger kun sjældent eller slet ikke bruger deres elektroniske udstyr, når de ikke er på undervisningstilbuddene. Dette leder både til tekniske problemer ved uhensigtsmæssig vedligeholdelse af udstyret, men vidner også om en mangel på interesse eller modvilje overfor at inkorporere teknologien i hverdagen.

Undervisningstilbuddene udfylder altså mange roller for forskellige brugere. Nogle brugere var kun interesserede $i$ at erhverve sig de specifikke kompetencer, der skulle til for at betjene sig af de nye løsninger, der var en del af digitaliseringsstrategien, og var ellers ikke interesserede $i$ at benytte sig af undervisningstilbuddene. I modsætning til dette, var der brugere der benyttede sig af tilbuddene gentagende gange, både med mere og mindre klare formål. Undervisningstilbuddene kunne både være et springbræt til, at de mest it-fremmede ældre kunne få lyst til, og mod på, at erhverve sig nye medieteknologier, og et sted, hvor konkrete problemer kunne løses hos de mere erfarne brugere. Omvendt kan tilbuddene også, $i$ kraft af deres indbydende rammer, blive den eneste arena hvor brugerne benytter sig af deres nye medieteknologier, og for andre brugere kan læren omkring nye medieteknologier blive en nærmest irrelevant ting, set i forhold til tilbuddenes mulighed for at være arenaer for socialt samvær. 


\section{Digital dannelse - også for ældre}

Underviserne inkluderet i denne undersøgelse har en selvlært tilgang til, og interesse for IKT, hvilket også kommer til udtryk i deres begrundelser for, hvorfor de har valgt netop denne fritidsbeskæftigelse. Deres motivation er som regel en variation over følgende citat:

Da jeg så blev pensioneret, så skulle jeg beskæftige mig med noget, og så valgte jeg at nyttiggøre mig ved at hjælpe nogle andre [...], og da mit hjerte brænder for IT, så blev det så IT jeg beskæftigede mig med. (Underviser C)

Undervisernes egen tilgang er altså som regel understøttet af en indre motivation for emne-materialet IT. De fleste undervisere talte da også ud fra en antagelse om, at deres brugere også var til stede på grund af et minimum af interesse $i$ at beskæftige sig med computermediet.

På det københavnske tilbud, hvor brugerne kunne komme og gå efter forgodtbefindende, udtrykte underviserne generelt et $\emptyset$ nske om at deres brugere skulle blive så selvstændige i deres it-brug som muligt. Én frivillig sammenligner det med sin tidligere erhvervserfaring fra et fritidshjem:

det ideelle ville jo være at vi lavede én eller to vejledninger til en sådan PC-Café og så kom brugeren aldrig igen, for så var brugeren blevet så selvkørende at så kunne problemer blive løst af ham selv eller hende selv. Det er i hvert fald sådan som jeg tænker det. Sådan har jeg i hvert fald også selv lært at omgås PC'er og it. (Underviser E)

Som det fremgår i citatet herover er undervisernes egen livserfaring altså præget af forestillingen om en vis mængde af gåpåmod, samt en benyttelse af en ven eller slægtning eller Bakardjievas såkaldte varme ekspert, til at skabe deres eget forhold til, og forståelse af it. Det at erhverve sig en digital dannelse, og blive selvstændig bruger af teknologierne, ses altså som en grundsten i hvad underviserne ønsker at lære deres brugere.

Min erfaring omkring de der ting... både at løse konkrete problemer og også at sætte en udvikling i gang hos brugeren. Og sådan var det også med børnene. Og det er jo helt generelt, sådan var det ikke bare med IT, det er jo med alt hvad jeg har beskæftiget mig med. Det er at sætte en udvikling i gang og sige 'Jamen vi starter der, og så næste gang jeg snakker med den samme person så har vi flyttet os derhen til og tager og løser problemerne der har opstået der.'[...]Fuldstændigt som i ethvert intermenneskeligt [sic] forløb så er der en udvikling hele tiden. (Underviser E)

De frivillige undervisere arbejder altså alle, omend i varierende grad, hen imod et billede af deres brugere som selvstændige it-brugere. De er dog også i høj grad bevidste omkring, at det som regel vil være en længerevarende proces. Som underviseren også udlægger i citatet herover, søger de altså en vedvarende og refleksiv proces. Dette er også et grundvilkår for en digital dannelse der ofte fremhæves i litteraturen (Buckingham, 2006; Drotner, 2008; Hoem, 2003; Nyboe, 2009; Levinsen og Sørensen, 2011; Løvlie, 2003).

Ud over denne refleksivitet, så udviser aktiviteterne på it-tilbuddene også en hensigt om at administrere kompleksiteten i samfundet (cf. Qvortrup, 2000). Som det tidligere er blevet berørt, og som jeg vil udlægge nærmere herunder, sker denne administration blandt andet i form af, at ældre med udgangspunkt i deres egen hverdag og interesser, og ikke i normative forskrifter, beslutter sig for, hvilke aspekter af det digitale liv de vil og ikke vil inddrage i deres liv.

\section{Indholdet af en digital dannelse}

Tidligere forskning har vist, hvorledes det er svært at få ældre it-fremmede til selv at udtrykke, hvad de ønsker at lære (Sawchuk \& Lafontaine, 2015). Da det københavnske tilbud i høj grad var fokuseret på problemløsning, var dette kun i begrænset omfang tilfældet her. Brugerne opsøgte dem oftest med klare gøremål for øje. På det syddanske tilbud derimod, hvor undervisning foregik i faste hold, havde underviserne et stort fokus på brugerinddragelse omkring undervisningsindholdet: 
Jamen, det er jo at jeg meget hurtigt fandt ud af at det ikke er mig der skal komme og sige at "Nu gennemgår vi det der". Jeg skal spørge eleverne "Hvad vil I have?". "Hvad vil I høre om?". Det har jeg meget hurtigt fundet ud af. Og det tror jeg at de er glade for. (Underviser D)

De emner der blev taget op på brugernes opfordring var af en meget varieret karakter. Særligt bemærkelsesværdigt var, at kun meget lidt af det var direkte relateret til tvangsdigitaliseringen. Selve Digital Post blev kun forholdsvist sjældent taget op. Underviserne tilskriver dette, at tjenester som e-Boks har hjemmesider, der efterhånden er brugervenlige nok til, at de fleste ældre brugere er med.

Ud over kontakten til landsdækkende organisationer igennem Digital Post, blev digital kontakt til mere lokale instanser, som for eksempel den lokale læge, også behandlet på det syddanske tilbud. Den stigende mulighed for digital kontakt til en lang række instanser, var altså noget, som underviserne og brugerne lagde stor vægt på.

Gængse Windows-programmer som Microsofts Office-suite blev også gennemgået, ofte med eksempler, der tog udgangspunkt i brugernes foreningsliv. Ud over dette, var der et stort fokus på tilbagevendende begivenheder, som brugerne ønskede at kunne tackle i deres hverdag. Herunder at sende billeder via e-mail, og på anden måde komme i kontakt med deres nærmeste.

En af underviserne havde som sit eget foretrukne emne at hjælpe brugerne med online handel. Han gjorde særligt meget ud af, at de skulle vise kritisk bevidsthed omkring priserne, og især at sammenligne dem med fysiske butikker.

I de ovennævnte eksempler ser vi hvordan at underviserne arbejder på at normalisere dagligdags gøremål via de digitale medier. Dette arbejder hen imod det pædagogiske ideal om at de digitale medier ikke skal ses som noget "andet" eller separat fra den "virkelige" verden (Christiansen og Christensen, 2010).

Den kritiske bevidsthed levede også videre $i$ gentagende diskussioner og instruktioner omkring brug af virusbeskyttelse på computeren, og generel beskyttelse imod skadelige software og handlinger online. Det var et hyppigt samtaleemne brugerne imellem i pauser fra undervisningen. Én underviser beroligede dog flere gange brugerne med at "vi pensionister er ikke så interessante [for hackere]."

Underviserne lod sig altså ikke begrænse af at fokusere på risici frem for muligheder, hvilket ofte er et problem for også unge mennesker, der skal udfolde deres digitale liv (se Third et al., 2014, s.30). Al denne undervisning og vejledning tog i høj grad udgangspunkt i undervisernes egen, ofte autodidakte tilgang til livet med computere, og var altså inspireret af brugernes ønsker.

Altså vi prøver på - på bedste vis - og viderebringe dem nogle ting som de - vi - føler de har brug for derhjemme. Det er svært at få dem til at komme med nogle emner, som vi skal igennem. Det er det. Men vi har forsøgt igennem lang tid og finde nogle emner som interessere dem, og som de kunne være glade for og sådan nogle ting. (Underviser $\mathrm{A}$ )

Mere kreativt betonede emner som billedbehandling og udarbejdning af hjemmesider blev også taget op. Selvom behandlingen kunne forekomme meget rudimentær, må man ikke underkende, at dette var noget som både undervisere og brugere udviste stor interesse for.

Ud over at mange, forholdsvist instrumentelle emner bliver behandlet, som nævnt herover, bliver der altså også behandlede mere fornøjelige emner. De mere fornøjelige og selvtjenende aspekter af at benytte sig af særligt nye medier, er et emne der ofte overses i litteraturen omkring ældre. Som Van Leeuwen og Westwood (2008) har påpeget, er det påfaldende hvorledes, at et emne som eksempelvis leg anses som essentielt tidligt i livet, og forsømmes eller bliver set ned på i alderdommen. På begge tilbud bliver der lagt vægt på, at de nye teknologier også kan byde på mange muligheder for underholdning, som én underviser udtrykker det: 
Og så nogen viser vi også, at der er mere at hente, end de måske aner [...] At der rent faktisk er meget at hente af underholdning og sådan noget ik'. Også andet end syvkabale. (Underviser B)

Underviserne søger altså at få de mere selvplejende og interessebetonede aktiviteter ind i brugernes liv. Dette er i stærk modsætning til megen offentlig diskurs omkring mere selvplejende aspekter af de digitale medier, eksempelvis videospil (se eks De Schutter et al, 2015; Iversen, 2015) eller tekstbehandling (se eks Charness et al., 2001) hvor kognitive og fysiologiske aspekter bliver betonet langt mere end de underholdende.

At tilbuddene blev opsøgt af folk med henblik på at pleje deres interesser, kunne blandt andet ses ved, at begge tilbud havde haft bes $\varnothing \mathrm{g}$ af forfattere, der søgte hjælp med deres arbejde. I det københavnske tilbud var det en allerede udgivet forfatter, der søgte hjælp med sin computer og sit tekstbehandlingsprogram. I det syddanske tilbud var det en ældre mand fra lokalområdet, der ville sammenfatte sine erindringer.

Overordnet set bliver ældre brugere og deres egne mål her taget alvorligt af underviserne. De kompetencer, som de $\emptyset$ nsker at opfostre i brugerne, tager for det meste udgangspunkt i brugernes egne ønsker og oplevelser, snarere end implicitte forskrifter fra Digitaliseringsstyrelsen. Det er ikke kompetencer til konkurrence, som "halvdannelsen" (cf. Kemp, 2015) bliver udskældt for, det er kompetencerne og refleksiviteten til at forfølge egne interesser i en verden der kan forekomme kompleks og uoverskuelig (cf. Qvortrup, 2000).

Den digitale dannelse, som jeg her har argumenteret for opstår i samspillet mellem bruger og underviser, består altså blandt andet af kompetencerne til at kunne udfylde de krav, som det offentlige stiller til digitale borgere, men den indeholder langt mere end det. Ud over dette består den af evnen til at kunne udvælge og pleje sine egne interesser via computermediet. Der er altså i undervisningen og vejledningen er klart fokus på muligheder med de nye teknologier, snarere end et fokus på farer og faldgruber med de nye teknologier. Samtidig bliver en vis grad af kritisk refleksion også plejet, i hvert fald i en sådan grad, at brugernes egen sikkerhed ofte indgår som centralt element. Frem for alt udviser underviserne en bevidsthed omkring denne dannelse som en vedvarende og refleksiv proces.

\section{På vej mod selvudslettelse?}

"Selvudslettelse" som et mål eller et endegyldigt resultat er en formulering, jeg har hentet fra en af underviserne. Det er en beskrivelse af, hvorledes antallet af pensionerede brugere, der aldrig før har været i kontakt med en computer, er på vej nedad, og at det kan mærkes på medlemstallet. Flere af underviserne understregede, at de oplevede en stor tilflugt af brugere i forbindelse med digitaliseringsstrategiens implementering. Mange af disse brugere tillærte sig dog hurtigt, hvad de selv opfattede som de nødvendige kundskaber, i forhold til at kunne håndtere digitaliseringsstrategien, for så at forsvinde igen.

Underviserne udviser i deres overvejelser omkring de faldende medlemstal en form for mediegenerationstankegang, hvor computeren for kommende generationer af ældre ikke længere er noget "andet", men derimod en naturlig del af hverdagen. Dette er også det ideal der benævnes af Christiansen og Christensen (2010). I dette scenarie vil de ældre brugere ikke få noget behov for at arbejde med disse IT-Tilbud.

\footnotetext{
Vi får jo ind i mellem nogle øhhh som aldrig har rørt ved en PC før. Men det bliver sjældnere og sjældnere. Fordi øhh de yngste blandt de ældre altså de der er sådan i slutningen af 60'erne og begyndelsen af 70'erne de har jo næsten alle sammen haft en eller anden arbejdsmæssig erfaring med IT. (Underviser B)
}

Det bliver mindre og mindre behovet fordi idag får de jo en tablet i hånden, når de bliver født og mobiltelefonen i den anden. (Underviser A)

Det er dog værd at overveje om befolkningen som helhed nogensinde vil have de nødvendige forudsætninger for at være fuldstændigt uafhængige af undervisningstilbud som dem jeg har unders $\emptyset$ gt her. Underviserne udtrykker her en betragtning, som går godt i spænd med forestillingen om mediegenerationer og disses forskellige forudsætninger og verdenssyn i relation til medierne, men en forestilling som mine observationer 
omvendt også indeholder modbeviser på. Som nævnt talte jeg med flere brugere, der havde en decideret computer-teknisk baggrund, og selv disse fandt det givtigt at søge hjælp.

Som tidligere nævnt er medielandskabet af en meget omskiftelig natur, og det vil det sandsynligvis blive ved med at være indenfor enhver overskuelig fremtid. Selv mindre ændringer i offentlige institutioners hjemmesider har, efter mine informanters eget udsagn, fået folk til at søge hjælp.

Desuden udelukker selv en grundig erfaring fra erhvervslivet ikke et behov for assistance eller en interesse for videreudvikling eller refleksion senere i livet. "Bare fordi du bruger computer hver dag, betyder det ikke, at du har digital dannelse" som Skov og Brøndum (2012, s. 6) formulerer det.

\section{Konklusion}

I denne artikel har jeg undersøgt to tilbud omkring assistance til it, der begge henvendte sig til ældre. Selvom der var forskelle på forholdene hos de to tilbud, så tegner der sig en overbevisende mængde fællestræk indenfor mit undersøgelsesområde. Det første formål var at afdække om disse tilbud kunne hjælpe ældre brugere med at "domesticere" nye medieteknologier, som computeren og internettet, og særligt de tjenester som er blevet implementeret i forbindelse med digitaliseringsstrategien. Underviserne på disse tilbud har tjent en lang række formål og har indtrådt en lang række steder i domesticerings-processen. De har både givet råd til brugere omkring indkøb af disses første computere, og bistået dem med installation af disse nye teknologier.

Et problematisk felt der dog blev klart, var at underviserne ofte berettede om brugere der ikke benyttede sig af deres computerudstyr udenfor tilbuddenes rammer, og derfor aldrig fuldstændigt "domesticerede" teknologien.

Begge tilbud oplevede en tilflugt af brugere der ønskede at tilegne sig kendskab til offentlige teknologier som Digital Post, så var det de færreste af disse der hang ved, når først de mente at have tilegnet sig de nødvendige kompetencer. Omvendt berettede underviserne om flere tilfælde af brugere, som fravalgte løsninger som NemID og Digital Post, men ikke fravalgte computermediet i deres hverdag. Følgeligt søgte disse brugere også hjælp på tilbuddene til andre formål. Blandt andet på denne måde kan undervisningstilbuddene siges at hjælpe de enkelte brugere med at administrere og reflektere over kompleksiteten i hverdagen (cf. Qvortrup, 2000) med de digitale medier. Dette var en af de årsagerne til at jeg valgte at inddrage begrebet "digital dannelse" i diskussionen af hvad underviserne stræber efter.

Dette bringer mig til artiklens andet forskningsspørgsmål. Her var formålet at belyse om den undervisning de frivillige forestod, var fokuseret på at leve op til de instrumentelle krav, der blev stillet til borgerne af digitaliseringsstrategien, eller om de havde et andet fokus. Her valgte jeg at inddrage begrebet digital dannelse.

Fokus i den eksisterende undervisning og vejledning var kun i mindre omfang præget af behovet for at leve op til de instrumentelle krav til, at deres brugere skal kunne interagere med det offentlige digitalt. Derimod er der et stort fokus på at skabe, hvad jeg har valgt at betegne "digital dannelse". Denne digitale dannelse tager udgangspunkt i brugernes egne interesser og behov, modsat instrumentelle krav til kompetencer, som Digitaliseringsstyrelsen implicit efterspørger i digitaliseringsstrategien. Brugerne bliver instruerede i at udvise en kritisk bevidsthed i mange af deres gøremål med de nye teknologier. Men ud over dette, bliver de også gjort bevidst omkring mere oversete aspekter (jf. Third et al., 2014; Van Leeuwen \& Westwood, 2008), herunder deres muligheder for udfoldelse og underholdnings-potentialet i de nye teknologier.

Disse it-tilbud må altså ikke forstås som udelukkende instrumentelt kompetence-givende, men også som tilbud der tager det voksne menneskes individuelle interesser alvorligt. Selvfølgelig skal det ikke forstås som at enhver bruger går fra disse tilbud som et "digitalt dannet" menneske, men blot at bestræbelserne og ambitionerne for underviserne ligger langt ud over det instrumentelle. 
Forfatteren har til udarbejdelsen af denne artikel modtaget finansiel støtte fra VELUX-fonden, Tobaksvejen 10, 2860 Søborg, Danmark.

\section{Referencer}

Almeida-Ferreira, S., Mealha, O., \& Veloso, A. I. (2017). Older Adults and Email Use: The challenges facing interface co-design. Networking Knowledge: Journal of the MeCCSA Postgraduate Network, 10(1), 44-63.

Aroldi, P., \& Colombo, F. (2007). Generational belonging and mediascape in Europe. Jsse-Journal of Social Science Education, 6(1). Hentet fra http://www.jsse.org/isse/index.php/isse/article/view/1038

Bakardjieva, M. (2005). Internet Society: The Internet in Everyday Life. 1 Oliver's Yard, 55 City Road, London EC1Y 1SP United Kingdom: SAGE Publications Ltd.

Bakardjieva, M. (2011). The Internet in Everyday Life: Exploring the Tenets and Contributions of Diverse Approaches. In M. Consalvo \& C. Ess (Eds.), The Handbook of Internet Studies (pp. 59-82). Oxford, UK: WileyBlackwell. Hentet fra http://doi.wiley.com/10.1002/9781444314861.ch4

Boje, T. P. (2014). Uformel frivillighed. In T. Fridberg \& L. S. Henriksen (Eds.), Udviklingen i frivilligt arbejde 2004-2012 (pp. 225-248).

Bonfadelli, H. (2002). The Internet and knowledge gaps a theoretical and empirical investigation. European Journal of Communication, 17(1), 65-84.

Boyd, D. M., \& Ellison, N. B. (2007). Social Network Sites: Definition, History, and Scholarship. Journal of Computer-Mediated Communication, 13(1), 210-230. https://doi.org/10.1111/j.1083-6101.2007.00393.x

Brandtzæg, P. B., Lüders, M., \& Skjetne, J. H. (2010). Too many Facebook "friends"? Content sharing and sociability versus the need for privacy in social network sites. Intl. Journal of Human-Computer Interaction, 26(11-12), 1006-1030.

Braun, M. T. (2013). Obstacles to Social Networking Website Use Among Older Adults. Comput. Hum. Behav., 29(3), 673-680. https://doi.org/10.1016/i.chb.2012.12.004

Buckingham, D. (2006). Defining digital literacy What do young people need to know about digital media? Digital Kompetanse, 1(4), 263-276.

Charness, N., Kelley, C. L., Bosman, E. A., \& Mottram, M. (2001). Word-Processing Training and Retraining: Effects of Adult Age, Experience and Interface. Psychology and Aging, 16(1), 110-127.

Christensen, C. L., Jerslev, A., Swane, C., \& Blaakilde. (2017). AEldre menneskers mediebrug. In C. L. Christensen \& A. Jerslev (Eds.), AEldre mennesker i et mediesamfund. København: Frydenlund.

Christiansen, R. B., \& Christensen, O. (2010). Lærerne og de nye vilkår, professionslæring og praksisrefleksion. København: UP - Unge Pædagoger.

Danmarks Statistik (2016). It-anvendelse i befolkningen 2016. København: Danmarks Statistik.

De Schutter, B., Brown, J. A., \& Abeele, V. V. (2015). The domestication of digital games in the lives of older adults. New Media \& Society, 17(7), 1170-1186.

DeWalt, K. M., \& DeWalt, B. R. (2011). Participant observation, a guide for fieldworkers (2. ed.). Lanham, Md: Rowman \& Littlefield. 
Digitaliseringsstyrelsen. (2012). It - barrierer, motivation og læring. Allerød: NIRAS Konsulenterne. Hentet fra https://www.digst.dk/Digital-inklusion/Analyser-undersoegelser-og-kortlaegninger/Ny-viden-om-hvordanendnu-flere-danskere-kan-faa-del-i-digitaliseringen

Drotner, K. (2008). Digital dannelse: Når fritiden er hårdt arbejde. In J. T. Bertelsen, A. H. B. Ebbensgaard, K.-A. Madsen, \& Mouritsen (Eds.), Viljen til visdom (pp. 138-148). Aarhus: Forlaget Slagmark.

Forsberg, L., Wendelboe, L., Müller, C., \& Folker, M. P. (2013). Senior Online: Det digitale Danmark set med 65+ $\varnothing j n e$. København: Teknologisk Institut: Center for Arbejdsliv.

Fridberg, T. (2014). Udviklingen i frivilligt arbejde 2004-2012. In T. Fridberg \& L. S. Henriksen (Eds.), Udviklingen i frivilligt arbejde 2004-2012 (Vol. 14, pp. 29-46). København: Socialforskningsinstituttet.

Friemel, T. N. (2016). The digital divide has grown old: Determinants of a digital divide among seniors. New Media \& Society, 18(2), 313-331. https://doi.org/10.1177/1461444814538648

Ganguin, S., \& Haubold, R. (2017). The Elderly's Media Appropriation as Variable for Target Groups. Networking Knowledge: Journal of the MeCCSA Postgraduate Network, 10(1), 27-43.

Harakkarainen, P. (2012). "No good for shovelling snow and carrying firewood": social representations of computers and the internet by elderly Finnish non-users. New Media and Society, 14(7), 1198-1215.

Henriksen, L. S. (2014). Baggrund og introduktion. In T. Fridberg \& L. S. Henriksen (Eds.), Udviklingen i frivilligt arbejde 2004-2012. København.

Hoem, J. (2003). Essay: Digital dannelse. KULT8801 - Forsking Og Samfunn, 1-12.

Iversen, S. M. (2015). Danish newspaper discourses on older adults and digital games. Presented at the NordMedia 2015, København, Denmark. Retrieved from

http://findresearcher.sdu.dk/portal/en/publications/danish-newspaper-discourses-on-older-adults-and-digitalgames(592e96a2-daf1-4ece-8658-88ddb9518d8a).html

Jæger, B. (2003). Trapped in the digital divide? Old people in the information society. Science \& Technology Studies, 28(2).

Kemp, P. (2015). Løgnen om dannelse. København: Tiderne Skifter.

Kim, H., Kim, G. J., Park, H. W., \& Rice, R. E. (2007). Configurations of relationships in different media: FtF, email, instant messenger, mobile phone, and SMS. Journal of Computer-Mediated Communication, 12(4), 1183-1207.

Kulturstyrelsen. (2015). Medieners udvikling i Danmark. København: Kulturstyrelsen. Hentet fra https://slks.dk/mediernes-udvikling-2015/

Kvale, S. (1994). Interview: En introduktion til det kvalitative forskningsinterview. København: Hans Reitzels Forlag.

Lampe, C., Vitak, J., \& Ellison, N. (2013). Users and Nonusers: Interactions Between Levels of Adoption and Social Capital. In Proceedings of the 2013 Conference on Computer Supported Cooperative Work (pp. 809-820). New York, NY, USA: ACM. https://doi.org/10.1145/2441776.2441867

Levinsen, K. T., \& Sørensen, B. H. (2011). Fremtidsrettede kompetencer og didaktisk design. CURSIV, (8), 13-34.

Livingstone, S., \& Helsper, E. (2007). Gradations in digital inclusion: children, young people and the digital divide. New Media \& Society, 9(4), 671-696. 
Løvlie, L. (2003). Teknokulturell danning. In R. Slagstad, O. Korsgaard, \& L. Løvlie (Eds.), Dannelsens forvandlinger (pp. 347-371). Oslo: Pax Forlag.

Madsen, C., \& Kræmmergaard, P. (2016). Warm Experts in the age of Mandatory e-Government: Interaction Among Danish Single Parents Regarding Online Application for Public Benefits. Electronic Journal of EGovernment, 14(1). Retrieved from http://www.ejeg.com/issue/download.html?idArticle=447

Melenhorst, A.-S., Rogers, W. A., \& Bouwhuis, D. G. (2006). Older Adults' Motivated Choice for Technological Innovation: Evidence for Benefit-Driven Selectivity. Psychology and Aging, 21(1), 190 -195.

Mollenkopf, H., \& Kaspar, R. (2005). Elderly people's use and acceptance of information and communication technologies. In B. Jæger (Ed.), Young Technologies in Old Hands: An International View on Senior Citizen's Utilization of ICT. København: Djøf / Jurist- og Økonomforbundet.

Nimrod, G. (2010). Seniors' online communities: A quantitative content analysis. The Gerontologist, 50(3), 382392.

Norris, P. (2001). Digital divide: Civic engagement, information poverty, and the Internet worldwide. Cambridge, UK: Cambridge University Press.

Nyboe, L. (2009). Digital dannelse, børns og unges mediebrug og -læring inden for og uden for institutionerne. København: Frydenlund.

Pfeil, U., Zaphiris, P., \& Wilson, S. (2010). The role of message-sequences in the sustainability of an online support community for older people. Journal of Computer-Mediated Communication, 15(2), 336-363.

Quinn, K., Smith-Ray, R., \& Boulter, K. (2016). Concepts, Terms, and Mental Models: Everyday Challenges to Older Adult Social Media Adoption. In International Conference on Human Aspects of IT for the Aged Population (pp. 227-238). Springer International Publishing. Retrieved from http://link.springer.com/chapter/10.1007/978-3-319-39949-2 22

Qvortrup, L. (2000). Det hyperkomplekse samfund: 14 fortællinger om informationssamfundet. København: Gyldendal.

Regeringen, KL, \& Danske regioner. (2011). Den digitale vej til fremtidens velfærd. Den fællesoffentlige digitaliseringsstrategi 2011-2015. København: Økonomistyrelsen.

Richardson, M., Weaver, C. K., \& Zorn Jr, T. E. (2005). “Getting on”: older New Zealanders' perceptions of computing. New Media \& Society, 7(2), 219-245.

Sawchuk, K., \& Lafontaine, C. (2015). Precarious Ageing: Questioning Access, Creating InterACTion. In EM 2015 : Proceedings of the Technology \& Emerging Media Track - Annual Conference of the Canadi an Communication Association. Ottowa.

Silverstone, R., \& Haddon, L. (1996). Design and the domestication of information and communication technologies: technical change and everyday life. In R. Mansell \& R.

Silverstone (Eds.), Communication by Design: The Politics of Information and Communication Technologies (pp. 44-74). Oxford, UK: Oxford University Press.

Silverstone, R., Hirsch, E., \& Morley, D. (1992). Information and communication technologies and the moral economy of the household. Consuming Technologies: Media and Information in Domestic Spaces, 15-31. 
Siren, A., \& Knudsen, S. G. (2014). AEldre og digitalisering: Holdninger og erfaringer blandt ældre i Danmark (No. 14:22) (p. 132). København: SFI - Det nationale forskningscenter for velfærd. Hentet fra https://pure.sfi.dk/ws/files/194234/1422 Aeldre og digitalisering.pdf

Skov, A., \& Brøndum, J. (2012). Sikker færd på nettet, digital dannelse for børn og unge.København: Arbejdernes Landsbank.

Sommer, F. M., Borchhorst, D. S., Sillesen, A., \& Heilesen, S. (2015). Styrkelse af ældres teknologikompetence gennem frivillighed. In M. Vestbo, R. Andersen, \& S. H. Thingstrup (Eds.), Brugerinddragelse og frivillighed: Mellem optimering og kritisk refleksion (pp. 31-44). Sorø: USCJ Forslag.

Stald, G., Hjelholt, M., \& Nielsen, L. H. (2015). Specialrapport: Media literacy i en dansk kontekst (Mediernes udvikling i Danmark). København: Kulturstyrelsen.

Sum, S., Mathews, M., Pourghasem, M., Hughes, I., \& others. (2008). Internet technology and social capital: How the Internet affects seniors' social capital and wellbeing. Journal of Computer-Mediated Communication, 14(1), 202-220.

Sundar, S. S., Oeldorf-Hirsch, A., Nussbaum, J., \& Behr, R. (2011). Retirees on Facebook: can online social networking enhance their health and wellness? (p. 2287). ACM Press.

https://doi.org/10.1145/1979742.1979931

Sørensen, K. H. (2004). Domestication The Social Enactment of Technology. Trondheim, Norge: Norge teknisknaturvidenskabelige universitet. Hentet fra

https://www.ntnu.no/c/document library/get file?uuid=fa9db74b-6155-4f6d-9434-

8bc1652a1911\&groupld=10265

Third, A., Bellrose, D., Dawkins, U., Keltie, E., \& Pihl, K. (2014). Children's Rights in the Digital Age: A download from children around the world. Melbourne: Young and Well Cooperative Research Centre.

Van Leeuwen, L., \& Westwood, D. (2008). Adult play, psychology and design. Digital Creativity, 19(3), 153-161.

Westlund, O., \& Weibull, L. (2013). Generation, life course and news media use in Sweden 1986-2011.

Northern Lights, 11(1), 147-173.

\footnotetext{
i NemID er en fælles log-in løsning til danske offentlige hjemmesider og netbanker. Løsningen blev taget i brug 1. Juli 2010.

ii Digital Post eller eBoks, er en online postkasse hvor personer med dansk CPR kan vælge at modtage post fra danske virksomheder, kommuner og offentlige institutioner.
} 